\title{
Misrecognition and Political Agency. The Case of Muslim Organisations in a General Election
}

\author{
Jan Dobbernack, Nasar Meer and Tariq Modood
}

\section{Research Highlights and Abstract}

This article:

- Examines the meaning of claims for 'recognition' and struggles against 'misrecognition' by working through aspects of Muslim political agency in contemporary British politics;

- Contributes to research on the political mobilisation of Muslims in Britain by examining how civil society organisations respond to perceived stigmas and project a Muslim civic identity;

- Contributes to research that investigates dilemmas of political agency between the pressure to conform to standards of neutrality and maturity, on the one hand, and creativity and opposition, on the other;

- Demonstrates how minority actors manoeuvre and position themselves in the unsettled environment of contemporary British politics.

It is a common complaint among Muslim civil society organisations that their presence in British politics is misconstrued. An increasing number of activists and groups are concerned to repudiate what they perceive to be the misperception of their political agency as exceptional and difficult to accommodate. Organisations and initiatives thus project and practice civic identities, to demonstrate that they are committed to the 'common good'. This article explores how a number of organisations positioned themselves in response to experiences of 'misrecognition' in the context of the General Election 2010. With this conceptual focus we explore one of the most pertinent characteristics of Muslim political agency in Britain today: how actors respond to perceived pressures, make claims and project identities in opposition to alleged misperceptions or the refusal to acknowledge their desired self-descriptions. The article draws on a set of qualitative interviews with representatives of advocacy organisations that mobilised Muslim constituents in the run-up to the General Election 2010.

Keywords: Muslim politics; misrecognition; General Election 2010; ethnoreligious diversity

\section{Introduction}

It is a common complaint among Muslim civil society organisations that their presence in British politics is misconstrued. For example, and notwithstanding a broader commitment to pluralism in British politics, activists who mobilise on the basis of Muslim religious identities often encounter the charge that they foster sectarian divisions. ${ }^{1}$ Hence, following his victory in the Bradford West by-election, 
a salient trope emerged that George Galloway's success owed everything to electoral choices made by a Muslim voting block. What was less immediately noted was the role of young voters and disenchantment with Labour's alleged exploitation of kinship networks (biraderi). Right-wing commentators meanwhile converged on the view that Galloway's success showed 'that sectarian politics are now alive and well in Britain' (Murray 2010) and that British Muslims eagerly responded when they were addressed 'not as primarily British citizens but solely as Muslims' (Pollard 2012). As an example for the 'ugly alliance between the far left and Islamists', Abhijit Pandya (2012) pointed to 'groups like Operation Black Vote and the Muslim Public Affairs Committee [that] are busy encouraging such communities to vote along racial and religious lines.'

There is of course a prevailing political context here. Organisations that attempt to mobilise minority citizens by appealing, in one way or another, to collective concerns, interests and identities, find themselves in situations where they have to respond to representations that they believe do not adequately characterise their objectives. Muslim participation in British politics is profoundly affected by this. In response, an increasing number of advocacy groups are concerned to repudiate what they perceive to be misperceptions of Muslim agency as exceptional and difficult to accommodate. Frequently, these organisations and initiatives seek to project and practice civic identities, to demonstrate their normality and a commitment to the 'common good'.

This article focuses on such efforts in the context of the general election 2010. It draws on qualitative research into campaigns of the most active mobilising actors: the Muslim Council of Britain (MCB), ENGAGE, the Muslim Public Affairs Committee (MPAC) the Youelect initiative, and, as a non-Muslim group, the aforementioned Operation Black Vote (OBV). A relevant similarity is that these groups have at times been accused of fostering extremism, while being more commonly blamed for encouraging British Muslims to engage in silos, away from the mainstream. These accusations are being made from across the political spectrum, including by co-religionists, such as the Liberal Democrat candidate for Hampstead and Kilburn, Maajid Nawaz. ${ }^{2}$ While the organisations whose work we survey here represent (with the exception of OBV) different shades of British Muslim politics, they all find themselves vulnerable to such accusations and feel the need to respond. The article explores this response and so allows us to bring pertinent features of British Muslim political agency into focus. This includes how actors respond to perceived pressures, make claims and project identities in opposition to alleged misperceptions or the refusal to acknowledge their desired self-descriptions. The article focuses on political agency in response to the experience of misrecognition. It deliberately chooses not to review in significant detail the socio-political and demographic context of British Muslim electoral politics. It equally does not address the reality of anti-Muslim bias, such as in the British press (see, however, the recent Ethnic Minority Election Survey; e.g., Sobolewska et al., 2011). Instead, we employ and problematise the concept of 'misrecognition' to help theorise these processes (see Moore, Mason and Lewis, 2008; McEnery, Baker and Gabriealatos, forthcoming 2013).

The article draws on a set of qualitative interviews with representatives of the organisations listed above that were conducted in early 2012. It supplements their 
accounts with a study of campaign materials published in the run-up to the general election. Developing the conceptual frame, the article begins by locating the concept of misrecognition within normative and political theory (Section 1). It then outlines fives 'modalities' of the experience of misrecognition that are discernible in how Muslim political actors conceive of their wider political environment (Section 2 ). After this, the article works through three significantly contested issues that require a response from all organisations under investigation: namely, minority representation (Section 3), the character of 'the Muslim Vote' (Section 4) and political neutrality (Section 5). It concludes by suggesting that misrecognition allows for a constructive perspective on Muslim politics but needs to be expanded in order to conceive of creative, rather than merely reactive, aspects of minority political agency.

\section{The Concept of Misrecognition}

Beginning with our theoretical concern, misrecognition is a term that is obviously relational to recognition, and the two most prominent proponents of the latter concept began their dialogues with the same source. Charles Taylor's (1994) essay on 'The Politics of Recognition' and Axel Honneth's (1994) book Kampf um Anerkennung engage with-both appropriating and departing from-Hegel's philosophical system. For example, shadowing Hegel's account of the three arenas of recognition (family, civil society and the state), Honneth argues that there are three modes of recognition, which he refers to as love, respect and esteem. Love is the mode of recognition which, all being well, we receive from our small circle of significant others. Respect is that mode which we experience when our fellow citizens regard us as rights-bearing individuals. Esteem is the sort of recognition we enjoy when we are valued for our distinct contributions to society's collective goals. Taylor, meanwhile, offers a philosophical and historical account of how recognition reflects 'a vital human need' $(1994,26)$, one crucial to our ability to become full human agents. This claim stems from the Hegelian premise of the fundamentally dialogical character of human identity which Taylor (1989) elaborated in Sources of the Self. That is, one can become a self, capable of self-understanding and achieving 'self-definition', only in relation to other conversation partners, within 'webs of interlocution' $(1989,32,36)$. In political terms, the concern with recognition thus allows us, as Nancy Fraser $(2013,4)$ acknowledges despite some misgivings about the concept, to 'broaden, and to radicalize, the concept of justice' by bringing into view the subject- and group-specific consequences of hitherto unnoticed forms of oppression, as well as the harm suffered by the systematic experience of social bias.

Interestingly, the two leading authors on recognition spend relatively little time elaborating on the circumstances of misrecognition (cf. Martineau et al. 2012; Meer et al. 2012). For Taylor, the concept is a taken-for-granted inversion of recognition. To those affected, he argues, misrecognition inflicts 'real damage, real distortion, if the people or society around them mirror back to them a confining or demeaning or contemptible picture of themselves' (Taylor 1994, 25). Honneth offers a marginally more sustained elaboration of misrecognition, regarding it as 'the withdrawal of social recognition, in the phenomena of humiliation and disrespect' (Fraser and Honneth 2003, 134). Yet in both cases the specifically political conditions for this harm to occur, or how those that are misrecognised act in response, is largely 
unexplored. In seeking to redress the lack of concern for political agency in such theorisations of recognition, Saba Mahmood (2005, 18, emphasis in original) highlights the 'capacity for action that specific relations of subordination create and enable'. Misrecognition, following Mahmood, is an unhelpful device if it is solely concerned with the assertion of pre-existing and stable identities that are articulated against social stigma. Instead, we should explore the subjectivities that emerge within social environments of subordination and misrecognition.

Regardless of the philosophical implications of Mahmood's position, this would require us to be contextually specific about the types of self-understandings that emerge in the case of minority politics, and so not to prejudge modalities of agency on the basis of uniform or detached conceptions of 'the' minority experience. It also means paying attention to how political identities and claims are adapted in conjunction with, rather than just asserted against, prevailing biases. Yet it still remains the case that a significant number of political actors who negotiate such biases do conceive of their social contexts as characterised by misrecognition and of themselves as misrecognised. Our discussion of their experience serves as a starting point for contextual inquiries into the struggle for recognition.

More recently, there has been a political turn in understanding misrecognition, as a means to contextualise political mobilisations that span different categories of political recognition: from seeking statehood (Seymour 2012; Staples 2012) to pursing participation in the public sphere as co-citizens (Lægaard 2012; Martineau 2012; Meer 2012). Indeed, we suggest that this is what makes it helpful to our interest in the strands and processes that make up Muslim political mobilisations. Rather than being a 'master concept' to conceive of justice and human selfrealisation, it can be an empirically sensitive instrument in analysing debates about formal participation and representation. As Honneth $(1994,274)$ himself suggests, it can deliver a 'critical, interpretive framework' to identify social conditions and discourses employed by actors that participate in concrete social struggles (see Thompson, 2012).

As such, misrecognition can provide for an empirically sensitive perspective. What actors, or groups of actors, do in response to the experience of misrecognition will depend on the type of bias they encounter and the discursive and material opportunities that are available to them. Unless they acquiesce or resign, misrecognised actors will seek redress and propose alternative truths that they wish to see socially acknowledged. Significantly, this might entail a challenge not only to individual biases or misperceptions but also to social rules and conventions. Thus, James Tully $(2000,479)$ suggests that when

a group puts forward a demand for recognition they seek to disclose the misrecognition or non-recognition in the existing rule of mutual recognition of themselves and others, to persuade others it is unjust and intolerable, and to display a preferred alternative.

Tully points to acts of 'disclosure' in which actors seek to defeat misrecognition not just by articulating alternative narratives but by embodying alternative selves. Such alternatives may then be registered (or not) by majority actors that revise their understanding of the minority in question. Ideally, it may lead to the revision 
of prevailing social conventions and established assumptions that structure misrecognition, such as those that account for the sensationalising coverage in parts of the mass media. Yet even when the desired form of recognition is not forthcoming, the proposition of alternatives might be empowering in its own right and there are numerous examples for how the assertion of oppositional identities, such as that of Black Power beginning in the 1960s, against the social mainstream has been experienced as profoundly positive by minority groups in question.

Drawing on this suggestion about reciprocal relationships in the struggle for recognition, there are three tendencies that we wish to highlight and that are open to contextually sensitive inquiry: (i) initial experiences of misrecognition, which motivate (ii) the disclosure of alternative truths or the embodiment of alternative identities, that are then (iii) socially acknowledged (or not). In the following, we focus on the first two of these moments. We wish to specifically address dilemmas of political agency and civic positioning in a difficult environment and thus examine how Muslim civic organisations respond to, are bound by and seek to transcend socio-political misrecognition.

\section{Misrecognising Muslim Agency}

Here, we discuss some of the constraints that characterise negative responses to the Muslim presence in British politics and outline on that basis five 'modalities' of misrecognition (see Table 1 below). In a first step, these modalities are loosely delineated, drawing on previous cases and discursive possibilities. We will then, in subsequent sections, apply and develop these modalities in a discussion of three contested examples.

As a general proposition, an equitable place for ethnic minority populations in British politics is relatively undisputed. However, progressives as well as conservatives frequently disavow political expressions that emphasise specific minority

\section{Table 1: Five Modes of Misrecognition}

M1 Misrecognising Muslim identity politics as markedly different in kind to other identity politics

M2 Misrecognising the dynamic positioning and complexity of Muslim identities and concerns

M3 Misrecognising Muslim agency as purely reactive, grievance-based or 'pariah politics'

M4 Misrecognising Muslim concerns as 'sectarian', not compatible with an orientation towards the common good

M5 Misrecognising Muslim political actors as 'toxic' and refusing political association 
markers or that prioritise minority requests (at the expense, for example, of overarching ideas or ideologies that are said to 'cover' or 'subsume' such requests). As already suggested, it is in particular the critique of 'identity politics' around which left- and right-wing commentators coalesce. For example, Douglas Murray (2010), the former director of the neo-conservative Centre for Social Cohesion, chastised in particular the Tories for appealing to Muslim voters and remarked that all

three of the major parties continue to think that the identity-group era of politics is still alive and well; that as part of the multiculti [sic] mindset it is inevitable that you say different things to different 'communities'; and that therefore you can say anything at all to get the alleged 'Muslim community' to vote for you.

On the Left, critics of 'identity politics' see disempowering effects of the political appeal to ethnic or religious identities for the communities in question and to how this emphasis reinforces hierarchies and strengthens conservative forces. In their manifesto, the New Generation Network (2006), for example, argued that in 'a throwback to the colonial era, our politicians have chosen to appoint and work with a select band of representatives and by doing so treat minority groups as monolithic blocks, only interested in race or faith based issues rather than issues that concern us all'. This critique, and the request to 'end communal politics', is particularly directed at the political mobilisation of kinship ties, biraderi in the case of Pakistani communities (see Werbner 1990; Anwar 1995; Purdam 2001), which have recently been identified as one reason for the wide-spread disenchantment that led to George Galloway's victory in Bradford West (Akthar 2012).

While specific features of minority mobilisations, for example on the basis of informal relationships between community leaders and the Labour Party, are perhaps open to critique, the attack on 'identity politics' has a tendency to conflate phenomena and stigmatise minority participation altogether. This is because Raceor faith-based mobilisations that happen to be bottom-up, do not necessarily perpetuate communal hierarchies and aren't manipulated by vested interests more than any other type of political assertiveness on the basis of shared concerns, are seen as an anomaly or ruled out as impossible. Identity politics tends to be identified with 'monolithic' groups, and there is, hence, a risk that this line of critique is selectively used to marginalise and silence some groups, especially new entrants. In fact, a type of misrecognition (la) that is identified by some of our respondents in this research is characterised by the rejection, often selectively, of group-or identity-based mobilisations in the case of Muslim political actors.

Such imbalances in the rejection of ethnic minority claims apply in debates about formal representation, too. Commentators criticise the concern with heightening ethnic minority representation for its single-minded pursuit of superficial similarity. Yet the meaning of political representation, and in particular the balance between is largely open (see Pitkin 1967; Phillips 1995; Young 2000). As Hannah Pitkin $(1967,210)$ suggests, the act of representation can be conceived in an abstract and disconnected way, akin to the Burkean 'representation of unattached interests', or as a particular and intimate connection where close ties between representatives and represented are necessary because 'interest, wants, and the like [are] definable only by the person who feels or has them'. It is not the case that in British parliamentary 
democracy, or more generally, the role of elected representatives is clearly conceived to follow either of these models; different expectations exist and claims can be modelled according to divergent understandings of what representatives are for and what representation is about. The suggestion that a Muslim 'politics of presence' or any other concern to increase the formal representation of specific minority groups is either exceptional or exceptionally problematic constitutes a related type of the same kind of misrecognition (lb). The conditions for the civic self-constitution of post-immigration groups are usually fragile and the request that they, sometimes even above all others, approximate idealised understandings of citizenship and democratic agency can be, and historically has been, an exclusionary device.

British Muslims are clearly some way beyond exclusion and in the aftermath of the Rushdie affair distinct patterns of their political agency became more widely acknowledged (Modood 1990; O'Toole et al. 2013). Yet it has been suggested that the experience of stigmatisation, in the aftermath of the Satanic Verses and exacerbated after 9/11, has led to political orientations that are primarily reactive and articulate grievances. There is a risk of reductionism in such accounts. British Muslim politics is characterised by diversity and, although the concern to defeat stigmas may be widely shared, political objectives differ in line with different religious, strategic and ideological commitments and follow distinct grammars of political agency (see O'Toole and Gale 2010). While ideological or religious commitments are clearly significant, they are not the only predictors of political activism among British Muslims. Some organisations, such as the MCB, liaise with decision makers and lobby behind the scenes. Others seek to effect political change through public engagement and awareness-raising (e.g. ENGAGE). Others, again, operate and mobilise predominantly locally, on the ground and through social networking sites (e.g. MPAC). The diversity of approaches, political sensibilities and the different ways in which religious identities are emphasised or have a background role reflects heterogeneity. The reluctance to acknowledge this diversity and the dynamism of political agency among British Muslims constitutes a second type of misrecognition that we propose to explore below (2).

In a similar manner, the emphasis on grievances means that the proliferation of alternative sites of Muslim civil society-in terms of media production and consumption, community and religious activism, and arenas for Muslim dissent-risks being ignored. This proliferation is considered as evidence of withdrawal rather than political pluralisation of the public sphere. Accounts that treat Muslim agency as purely reactive face a related objection. It is hardly the case that outside pressures always determine the political agency of marginalised groups; at least they usually do not give a good account of motivations and purposes that exist beyond the concern to overcome pressures. 'Excluded groups', Modood (2005, 159, emphasis in original) suggests, 'seek respect for themselves as they are or aspire to be, not simply a solidarity on the basis of a recognition of themselves as victims; they resist being defined by their mode of oppression and seek space and dignity for their mode of being.' The request for recognition entails the demand for spaces of self-expression that, instead of being governed by narrow justificatory constraints, allow for the free choice and proud articulation of different types of identities (Modood 2012, 2013). 
A valid assessment must therefore be sensitive to the emergence of Muslim identities that are adopted and deployed in various permutations by many Muslims themselves. A key issue is how this 'Muslim-consciousness' connects to the sorts of civic status that Muslims are seeking (Meer 2010). The types of civic status being referred to include those that have prevailed for other minorities under the terms of a peculiarly British multiculturalism, and which have sought to promote equality of access and opportunity, and have led to some significant recognition of particular minority 'differences'. In this domain and in arenas of political participation more generally, the concern to project political identities is as evident as the desire to overcome pressures. Its portrayal as driven by and reducible to grievances, purely reactive to outside pressures and devoid of positive political objectives, indicates a third type of misrecognition (3).

There has been a tendency, moreover, to reject mobilisations on the basis of minority identities for its alleged incompatibility with a political orientation towards the 'common good' (4). A historical account of this position within the Labour Party has been vividly brought out by Les Back and John Solomos (1992). In Birmingham's Small Heath, the contender for the 1992 Labour candidacy-current incumbent Roger Godsiff-was challenged at selection meetings by minority candidates. Godsiff enjoyed support from trade unions and the national party; his eventual selection, however, was marred by allegations of vote-rigging. Godsiff defended his position and suggested that the

trouble with people trying to become MPs now, they're trying to become MPs because they're members of an ethnic community, they're not trying to become MPs because they concern the whole of the community and they represent a philosophy. They don't understand that, they need to stop to think about it. I have to tell my councillors, some of whom aspire to become MPs, that their job is to represent all the constituents they've got, and often they're not very successful at it. And that's sad, so they still are not fully integrated into the Labour party, never mind the community (Interview with Roger Godsiff, MP, quoted in Back and Solomos 1992, 11).

The suggestion appears to be that in order to be representative-to embody, for example, the 'Labour philosophy'-minority concerns have to be abandoned. It is moreover the responsibility of minority politicians to prove their ability to represent: a burden that does not usually apply to white politicians, not even in constituencies with significant post-immigrant populations, such as Small Heath (43 per cent in 1992). The suspicion, and a related type of misrecognition that we explore in the following (4), is that Muslim agency reflects 'sectarian' interests-a suspicion that can only be appeased through continuous demonstrations of a commitment to the 'common good'.

A final obstacle, frequently encountered by Muslim political actors, is the difficulty to forge alliances as a result of the perceived toxicity of Muslim concerns. It is clear that different organisations deal differently with such difficulties. The MCB, for example, has sought to establish collaborative relationships across the partypolitical spectrum. MPAC, on the other hand, adopts a more combative posture: while it endorses candidates, it maintains distance since the association could 
potentially be damaging to its endorsees. Considerations about the due proximity and distance, as well as neutrality and partisanship, are widely evident in the strategic thinking of the mobilising actors that we have interviewed. The toxicity of the Muslim association constitutes on final experience of misrecognition that we investigate in the following (Section 5).

\section{The Politics of Muslim Representation}

It is worth registering at the outset that Muslim activists, particularly those operating with a view to the national level, often seem strongly attuned to their political environment and thus show considerable reflexivity about dilemmas of formal representation. For example, a respondent for The Cordoba Foundation, who was involved in the Youelect initiative to mobilise Muslim voters, highlighted in fairly stark terms one of the problems entailed in a mere focus on increasing the parliamentary minority presence:

We have one or two Muslim MPs that are absolutely dreadful. They happen to be Muslims but actually, they're dreadful, and most of their positions, you know, vis-à-vis the Muslim community, are totally negative. It doesn't really matter that they're Muslim (Interview, 9 January 2012 ).

The ability to judge candidates on the basis of their policy record rather than their faith, this respondent suggested, proved that the Muslim community is issuebased, and not religion-based' (Interview, 9 January 2012). Indeed, in the debate about political representation activists frequently appear to disavow the concern to heighten the Muslim presence in public institutions and highlight sophisticated, issue-based deliberations that they either see at work or want to promote among Muslim citizens. It is likely that frequent portrayals of Muslim political agency as 'tribal' or 'sectarian', and thus pre-modern and unenlightened, account for the vehemence with which this sophistication among Muslim voters is highlighted.

This is particularly evident in the reference to Muslim mobilisations against Muslim candidates, which were positively highlighted for how 'ideas' trumped 'religion': MPAC, for example, lobbied against Khalid Mahmood's re-election in Birmingham's Perry Bar constituency and claimed that, while Mahmood had 'relied on the Muslim vote to keep him in power', we 'are asking what did he do to stop the illegal wars abroad against Muslims and what did he do to stop the demonisation of Muslims in the UK' (MPAC 2010). A similar line of attack was adopted in the Bradford West by-election where MPAC endorsed Galloway and campaigned against Labour's Imran Hussein: 'to sweep aside the tired old pattern of voting in lack lustre candidates, just because they wear a red rosette' (MPAC 2012). NonMuslims were favoured over Muslim candidates, and this was noticed and indeed highlighted as a rejection of the unthinking support for Labour and co-religionists that was seen to have plagued a previous era of Muslim politics.

Elaborating on this type of strategic thinking, a respondent for MPAC suggested that 'we're not just saying: more Muslim MPs. What we're saying is that non-Muslims MPs also need to address the concerns of their Muslim constituents, which we feel in a large extent are being ignored' (Interview, 28 January 2012). For the MCB, a 
respondent agreed that certain types of community politics, which he labelled as the 'politics of representation', were detrimental to Muslim interests: 'unity is dissipating where you have vested interests competing for that patronage for government access'. This, he suggested, was 'damaging to the community itself and damaging especially to the younger people' (Interview, 12 January 2012).

There is some concern, moreover, that an increased Muslim or minority presence in institutions might not further the cause of equality but serve to conceal the lack of serious, issue-based commitment to racial and religious equality. Commenting on the policy record of the current government, a respondent suggested that 'we have a party that's beginning to look like the people it serves and yet [...] race equality [is] going further and further away. Multiculturalism [is] being trashed' (OBV, Interview, 2 February 2012). The concern is that a 'politics of presence' (Phillips 1995) achieves little if it is not accompanied by a critical concern with policy-making after elections. While the representative for $O B V$ highlighted the value of increased ethnic minority representation, it is striking that Muslim mobilising organisations often appear to accord only secondary, if any, significance to this objective.

A representative of Youelect highlighted a different set of problems. He pointed to persistent doubts about the Britishness of British Muslim, reflecting a situation where Muslim political agency was considered sectarian by default and thus incompatible with the 'common good': 'at the moment, unfortunately, any Muslim, either public figure or otherwise, is first a Muslim, then British and therefore his views are first pinned down to his Islamic identity rather than the British identity' (Interview, 25 January 2012). This leads to a situation where British Muslims 'are asked to make choices that no other groups are asked to make-their identity of being Muslim or British first'. A different respondent pointed to his own political activism, which included a candidacy for Respect, as an example for a similar experience of misrecognition: 'One of the most common questions that came my way was, you know, "If you decided to do this, why don't you go and establish a Muslim party?" ' (Interview, 9 January 2012). His response would be that 'we don't need a Muslim party, we're calling for Muslims to be part of society, I don't want them to stand on one side'.

Among those involved in the 2010 mobilisation there was thus a measure of concern about dilemmas of representation and in particular about the way Muslim political actors were forced to abjure their Muslimness in order to claim a more encompassing political identity. At the same time, the notion that increased representation would provide a remedy to inequality that could be achieved without serious and issue-based commitments was widely denounced. Arguably, one of the background conditions for this rejection of the 'politics of presence' was the concern to counter simplistic, but pervasive, representations of Muslim politics as premodern. There clearly is a strong concern to dispute accounts that equate Muslim agency with sectarianism and patronage politics and to emphasise and practise an alternative idea of political sophistication and maturity.

\section{Conceiving of the 'Muslim Vote'}

The 'Muslim Vote', and how Muslim political actors conceive of its significance and coherence, points in a different direction for our concern with the type of political 
positioning that emerges in contexts of misrecognition. As with formal representation, there are ambiguities to consider that are, to some extent, the reflection of a difficult environment. The aspiration to 'normalise' the participation of British Muslim-to emphasise that a block vote does not exist, or to argue that block-like voting instincts need to be overcome-is an evident concern among all of the respondents in our research. To some extent, this position implies a disavowal of 'groupness' and leads to strategic contradictions, such as when an emphasis on group coherence-such as on the potential for Muslim constituents to 'swing' elections-is considered strategically advantageous.

Highlighting diversity within the 'Muslim Vote', organisations involved in the 2010 mobilisation are also identifying features of the political environment that tend to negatively affect all British Muslims. An MPAC respondent, for example, suggested that although 'there's a great deal of diversity amongst Muslim communities, always in the plural rather than singular [...] we can potentially be all victims of anti-terror legislation, stop and search, lengthy detention without charge, these sorts of cases' (Interview, 28 January 2012). MPAC, however, appears to be an outlier among organisations that operate on a national level as it tends to frame its activism with reference to the global community of Muslims, the ummah. Other organisations appear more cautious in highlighting their encompassing concerns: 'oppression, we don't accept it whether it is against Muslims or against any human being' (Interview, 11 January 2012). Whether injustices that were seen to be impacting in particular on British Muslims or Muslims globally should be addressed as Muslim-specific, maybe even Muslim-exclusive, is thus somewhat contested. The reference to universal concerns, as it is evident in the MCB's public commitment to 'working towards the common good' appears to contrasts with MPAC's emphasis. Since a broad commitment to justice can be inferred from Islamic scripture, and is evidently shared among the organisations in question, these different emphases are not necessarily the result of theological disagreement but of differences about how to address target audiences, such as in relation to sensitive foreign policy issues and how to access mainstream political channels.

Asked about the extent to which it was possible to speak of a 'Muslim vote', a representative for Youelect suggested that it was difficult to pinpoint 'whether the Muslim identity itself can determine which way they're going to vote or their personal factors, like any economic profession and country of origin' (Interview, 25 January 2012). Equally, the Muslim Council of Britain's mobilisations reflect this uncertainty: 'the needs and aspirations of Britain's Muslim community are no different from those of our fellow citizens-whatever their beliefs or backgrounds' (MCB 2005, 3). In 2010, the MCB suggested that 'the Muslim voter, like any other Briton, may well make discerning choices of which their "Muslim identity", if ever there was one, is only a part of a menu of considerations' (MCB 2010). Highlighting the issue of apathy among young voters, an MCB representative emphasised the importance of social trends: 'We cannot just use Muslim factors when asking ourselves why there are low numbers' (Interview, 12 January 2012). In order to explain patterns of political behaviour amongst Muslim voters, the suggestion is that religious identities are one aspect, and not necessarily the most important one, that needs to be considered. 
Other activists carefully distinguished between the problematic nature of the 'Muslim vote' and the legitimate concern to mobilise on the basis of shared Muslim interests. A representative of ENGAGE, for example, indicated her uneasiness about the idea of a 'Muslim Vote' 'because it kind of condenses and generalises and homogenises something that I think is a much more complex phenomenon' (Interview, 3 February 2012). At the same time, the respondent indicated that the rejection of this concept reflected the exceptional status of Muslims who should 'have the freedom to associate, and by virtue of association [to] create organisations' (Interview, 3 February 2012). This question about the coherence of the Muslim Vote and an awareness of complexities within the British Muslim demographic should not be used to discredit mobilisations on the basis of shared interests and identities, in particular not where these associational freedoms are unproblematically granted in the case of non-Muslim social identity groups.

With regard to the basis on which Muslims should mobilise, a different respondent argued along similar lines: 'I'm not someone who favours religious politics, but I believe that there is a call for religious politics at a time when a particular religion is being targeted' (Interview, 9 January 2012). The experience of stigmatisation, he suggested, had forged a politically salient identity. Yet the respondent equally argued that this political salience should be embraced for its positive potentials, rather than being rejected as abnormal or exceptional.

If religion becomes a catalyst towards people taking part in a democratic process, I'm happy with that. If football becomes the catalyst for people to take part in something that is, you know, a democratic process, I'm happy for that. [...] We have, you know, communities or groups with interests, you know, whether based on ethnicity, race, religion, colour, creed, hobbies, leisure, entertainment, we have that. But we're talking about it as sort of an issue or a problem even simply because of the type, of the context, because we're operating within a context that is defined by $9 / 11$, it's defined by 7/7, it's defined by terrorism, it's defined by extremism, it's defined by wars, it's defined by, you know, all these issues (Interview, 9 January 2012).

The stigmatisation of Muslim identity in the public sphere, however, meant that some organisations treaded more carefully in the framing of their political messages. Youelect, for example, chose not to prominently highlight Muslim-specific issues or even identify Muslims as its target group on its website. The concern, as the person in charge of the initiative suggested, was that anything with 'the pre-fix of Islam or Muslim has a negative connotation immediately and I think there's a counterproductive element there' (Interview, 25 January 2012). In contrast to such concerns about the risk of being dismissed or negatively perceived, other organisations appeared to see a certain strategic benefit in highlighting a Muslim agenda: an 'acknowledgement that this is a constituency that they [politicians] cannot ignore' (Interview, 2 February 2012). Despite difficulties in identifying a 'Muslim Vote', the appeal to this concept could help to increase the public visibility of important issues that would elicit a response from campaigning politicians.

Yet the concern remains an emphasis on the 'Muslim Vote' might encourage a certain intellectual laziness that was characteristic for how ethnic minority groups 
had been engaged in the past. The benefit of rejecting simplistic categories and of highlighting the multiplicity within groups would be, a respondent for ENGAGE argued, that

you're able to populate that space and give voice to all the different perspectives that exist in the Muslim community, and it to me can only be a very good thing. Because it means that when politicians are looking around for a Muslim voice, they're all automatically confronted with Muslim voices, and they have to get over this idea that, you know, a Muslim voice will suffice, because they're confronted with a cacophony of voices and you have to deal with that cacophony. And annoying as it is, you have to deal with it, because that's the reality of the British Muslim community (Interview, 3 February 2012).

The diversity among representative organisations would thus reflect the complexity of Muslims as a social group and make it more difficult, it is hoped, to deploy simplistic categories when accounting for British Muslim politics. At the same time, this emphasis on multiplicity might constitute a constraint if it hampers associational freedoms, the articulation of shared concern and the use of Muslim electoral significance as a bargaining chip. In this case, a context of misrecognition appears to account for a choice between unsatisfactory alternatives.

\section{Limits of Neutrality and Partisanship}

As in debates about conceptions of the 'Muslim Vote' and representation, Muslim activists have discussed the issue of neutrality in a way that reflects difficult choices. In particular the 2008 election for London Mayor appears to constitute a crucial case. Widely considered sympathetic to their concerns, Labour's Ken Livingstone benefited from Muslim support, such as that of a number of well-known activists within the Muslims4Ken initiative. Yet Livingstone lost the election and there were some concerns that Boris Johnson had been portrayed in a way that would make it more difficult for Muslims to engage in London politics. During the campaign, MPAC had urged its supporters to 'help save us from a Zionist Islamophobe becoming Mayor of London' (MPAC 2008). Responding to controversial statements by Boris Johnson, Muslims4Ken portrayed the Conservative candidate as an 'Islamophobe who has insulted and condemned Islam and Muslims' (cited in Siddiqui 2008). ${ }^{3}$

In the Guardian, Asim Siddiqui attributed Livingstone's defeat to the backlash that these allegedly inapt efforts had triggered in particular among the capital's predominantly right-wing press. Siddiqui pointed to the 'kiss of death' that the association with Muslims4Ken had meant for Livingstone and to the radioactive affect [sic] of reactionary Islam in a post-7/7 London. [...] If the very candidate you are endorsing is being damaged by your endorsement, then surely it's time for a rethink' (Siddiqui 2008). Disputing this account, Anas Altikriti took particular issue with the assumption that led Siddiqui to the conclusion that it was time to stop to mobilising the 'Muslim vote' (Siddiqui 2008). Altikriti argued that '[t]o suggest that while Muslims can come under collective attack, suspicion and scrutiny as a result of crimes committed by a few, but can only defend themselves and fight for their rights as 
individuals, is nothing short of absurd-discriminatory, even' (Altikriti 2008). Siddiqui's call for caution, Altikriti argued, merely reflected the stigmatisation of British Muslims as a 'special case' and mainstream attempts to discredit any collective articulation of Muslim political concerns.

Strategic considerations about how to mobilise voters in the run-up to the general election, two years after Livingstone's first defeat, seemed to take account of this experience. The MCB, for example, which had not endorsed Livingstone, felt encouraged in its position of neutrality. An MCB respondent pointed to the significance of the mayoral campaign and argued that 'it wasn't for MCB to endorse', but rather just to 'do everything in terms of [...] raising issues, but stop short of saying who to put in their ballot box. It's more of service facilitation. You make your own mind up' (Interview, 12 January 2012). The same MCB respondent suggested that the fact that a political campaign had used the notion of a 'Muslim Vote' in support of a specific candidate constituted an anomaly, similar to Siddiqui (2008) who observed that there had been no 'JewsforBoris' or 'GaysforBrian' campaigns: 'You don't have a chief rabbi supporting a campaign for Boris' (MCB, Interview, 12 January 2012). As a representative umbrella body, the MCB saw it necessary to maintain neutrality - despite clear affinities with Ken Livingstone and the Labour party-in order to be able to engage with elected representatives regardless of their party background.

In the campaigns to mobilise Muslim voters in 2010, there were related differences of strategic positioning. Youelect, similar to the MCB's objective, primarily intended to familiarise Muslim voters with issues and candidates' policy record. Just before the election, however, it published links to two lists of recommended candidates. ${ }^{4}$ A respondent introduced the rationale for this departure from a more neutral position as follows:

... up until, I think it was the final week or the final two weeks, we didn't favour one over the other. We just said this is the information, these are the priorities, here's how it works, you go and decide, and you go and decide by meeting in your mosques and your community centres, in your homes, by talking, by discussing, by holding people accountable, asking them questions. [...] it was only towards, I think, the last week or 10 days of the elections that we started to come up with the idea of the lists, that, okay, fine [...] we feel that now is the time when we should say well, listen, there are some really very bad candidates and regardless of where they stand on the playing fields, they are really, really bad candidates (Interview, 9 January 2012).

A different respondent similarly suggested that 'people appreciated the fact that we [Youelect] weren't spoon-feeding them or we're not dictating on what they should be doing, we were simply directing them' and that 'people did feel empowered through Youelect but making sure we didn't encroach on their personal political space' (Interview, 25 January 2012). Accordingly, the reason why the initiative eventually offered voting recommendations was in response to 'a lot of push coming from the community itself'. 
By contrast, ENGAGE provided background information without offering recommendations and it was suggested that it 'would never advocate that you vote for this particular candidate, because it would be irresponsible to be fair, but also because it's the local communities that determine which candidates they want to elect' (Interview, 3 February 2012). MPAC, on the other hand, was directly targeting in particular those candidates that rejected, for example, for their support of the war on Iraq and alleged anti-Muslim positions. Without aiming for neutrality in its local interventions, MPAC nonetheless did not endorse any party. It was suggested for MPAC that

we have to be careful about how we position ourselves. So when we campaign, we campaign as an independent group, we are not in the pockets of anyone that we are trying to promote because what happens is, that can be used against them. So we're backing a candidate, for example from a party, his opposition will simply try to portray us as extremists and that this candidate is in the pocket of that group. So deliberately what we do is we keep distance from any candidate that we endorse. We're not asking for their endorsement. We're endorsing them. (Interview, 28 January 2012)

For MPAC, the portrayal as 'extremist' was profoundly at odds with their stated purpose: 'accusing people who are pro-democracy of having some kind of violent, extremist agenda. It's nonsense' (MPAC, Interview, 28 January 2012). Accordingly, while being opinionated and often less moderate in their messaging than other campaigning actors, MPAC sought to tread carefully in its relationship with the politicians that it endorsed and thus to avoid the 'radioactive effects' that (allegedly) had damaged Ken.

\section{Conclusion}

Traversing debates about the Muslim presence in British electoral politics, the article has examined ways in which Muslim organisations respond to, are bound by, and transcend the experience of misrecognition. Through empirical studies of activist organisations, we draw attention to the different ways in which these organisations speak about Muslim identities and seek to address Muslim concerns. This occurs within, and so is not immune from, a wider political landscape in which questions of minority agency are unsettled. The speech acts and positions investigated in this article reflect the attempt to respond to this landscape and to challenge misrecognition.

Although misrecognition is not an unproblematic concept, it corresponds to how activists that we have interviewed perceive features of the mainstream response to their political presence. We have highlighted the need to be contextually sensitive in examining their civic and political claims; these are not merely asserted against, but modulated and defined in relation to the experience of misrecognition. We contend that this accounts for specific dilemmas such as in relation to the recurrent emphasis on maturity and sophistication, which is perhaps the most widely shared point of reference in the rhetoric of the various initiatives that we have explored. Although this emphasis appears to offer a strong challenge to portrayals of Muslim 
agency as 'sectarian' and 'exceptional'—along the modalities of misrecognition outlined above-it also reflects some ambiguities. While the definition of the 'Muslim Vote' as the sum of mature, discerning and ideas-based choices may hold strategic benefit, it may also limit the room for political manoeuvre, cement a special status and thus impede a normalisation of the Muslim presence in British political life. The need to address misrecognition with political maturity constitutes an additional burden for Muslim political agency.

Such contexts suggest that minority political agency is shaped, though not necessarily determined, by the experience of misrecognition. The categories of British Muslim politics continue to develop in response to this experience, and there are potentials that lie in the articulation of new identities from within a state of misrecognition. Hence, although misrecognition has been our focus, we do not suggest that it provides the complete story. Experiences of misrecognition are not adequately understood if they are seen to be merely oppressive, limiting spaces for agency and being met by coping strategies and a posture of defensiveness. The political positioning that is evident among the organisations examined in this article shows that constraints are often creatively negotiated and that perceived pressures invite a significant degree of reflexivity and strategic awareness. Although these are challenging times for confident expressions of Muslim identities in British politics, there are some indications that political actors succeed in projecting political subjectivities that are not simply determined by the experience of misrecognition. The diversity of attempts to delineate such identities, as is evident among the mobilisations examined in this article, might indeed make it more difficult for Muslim political claims to be stigmatised as 'exceptional' or rejected.

\section{About the Authors}

Jan Dobbernack, European University Institute, Badia Fiesolana, Via dei Roccettini 9, I-50014 San Domenico di Fiesole (FI), Italy, email: jan.dobbernack@eui.eu

Nasar Meer, Faculty of Humanities and Social Sciences, Strathclyde University, Glasgow G1 1XQ. Scotland, www.nasarmeer.com

Tariq Modood, School of Sociology, Politics and International Studies, University of Bristol, 1.08, 3 Priory Road, Bristol, BS8 1TX, UK, email: t.modood@bristol.ac.uk

\section{Notes}

The authors acknowledge co-funding through the European Commission under its Seventh Framework Programme (Grant Agreement no. 243837). We are also grateful for the constructive comments from two anonymous referees.

1. Iris Young distinguishes between 'identity politics', understood as 'solidarity-producing cultural politics' $(2000,103)$ and the 'politics of difference', in which claims for 'fairness, opportunity, and political inclusion' $(2000,107)$ emphasise, but are not reducible to, specific cultural markers. It is not the point here to argue for this type of nuance in political rhetoric, yet it is clear that the popular critique of 'identity politics' is often simplistic and confused.

2. In his criticism of the MCB, Nawaz (2012) highlights the "unhealthy nature of communalist identity politics, and my preference for the citizenship model over the "umbrella" model, except in dealing with narrow religious matters'. We owe the reference to Nawaz to one of our anonymous reviewers.

3. This condemnation was later rephrased in somewhat less drastic terms, suggesting that 'Boris Johnson [...] has insulted women, blacks, Muslims and many other groups' (http://muslimsforken .blogspot.com/). 
4. One by the British Muslim Initiative, an organisation closely connected to Youelect, the other by Salaam.co.uk.

\section{Bibliography}

Akthar, P. (2012) 'British Muslims have given David Cameron an object lesson in democracy', The Guardian, 13 April. Available online at: http://www.guardian.co.uk/commentisfree/2012/apr/13/ british-muslims-david-cameron-democracy.

Altikriti, A. (2008) 'We got out the vote', The Guardian, 4 May. Available online at: http://www .guardian.co.uk/commentisfree/2008/may/04/wegotoutthevote.

Anwar, M. (1995) 'Social networks of Pakistanis in the UK: A re-evaluation', in A. Rogers and S. Vertovec (eds), The Urban Context: Ethnicity, Social Networks and Situational Analysis (Oxford: Berg), 237-257.

Back, L. and Solomos, J. (1992) Who Represents Us? Racialised Politics and Candidate Selection (Birkbeck College, University of London: Research Papers No 3 May 1992).

Fraser, N. (2013) Fortunes of Feminism. From State-Managed Capitalism to Neoliberal Crisis (London: Verso).

Fraser, N. and Honneth, A. (2003) Redistribution or Recognition? A Political-Philosophical Exchange (London: Verso).

Honneth, A. (1994) Kampf Um Anerkennung: Zur Moralischen Grammatik Sozialer Konflikte (Frankfurt am Main: Suhrkamp).

Lægaard, S. (2012) 'Unequal recognition, misrecognition and injustice: The case of religious minorities in Denmark', Ethnicities, 12:2, 197-214.

Mahmood, S. (2005) Politics of Piety: The Islamic Revival and the Feminist Subject (Princeton, NJ: Princeton University Press).

Martineau, W. (2012) 'Misrecognition and cross-cultural understanding: Shaping the space for a "fusion of horizons"', Ethnicities, 12:2, 161-177.

Martineau, W., Meer, N. and Thompson, S. (2012) 'Theory and practice in the politics of recognition and misrecognition', Res Publica, 18:1, 1-9.

MCB (2005) 'Electing to deliver', Muslim Council of Britain. Available online at: http://www.mcb.org.uk/ vote2005/ELECTINGTODELIVER.pdf.

MCB (2010) 'The "Muslim vote"—does it exist?', Muslim Council of Britain. Available online at: http:// www.muslimvote.org.uk/index.php?option=com_content\&view=articlesid=97\&Itemid=159.

McEnery, T., Baker, P. and Gabriealatos, C. (2013, forthcoming) Discourse Analysis and Media Attitudes: The Representation of Islam in the British Press 1998-2009 (Cambridge: Cambridge University Press).

Meer, N. (2010) Citizenship, Identity and the Politics of Multiculturalism (Basingtoke: Palgrave MacMillan).

Meer, N. (2012) 'Misrecognising Muslim consciousness in Europe', Ethnicities, 12:2, 178-196.

Meer, N., Martineau, W. and Thompson, S. (2012) 'Misrecognition and ethno-religious diversity', Ethnicities, 12:2, 131-141.

Modood, T. (1990) 'British Asian Muslims and the Rushdie affair', The Poltical Quarterly, 61:2, 143-160.

Modood, T. (2005) Multicultural Politics: Racism, Ethnicity and Muslims in Britain (Edinburgh: Edinburgh University Press).

Modood, T. (2012) 'Is there a crisis of secularism in Western Europe?'. Sociology of Religion, 73, 1-20.

Modood, T. (2013) Multiculturalism. A Civic Idea (2nd edn.) (Cambridge: Polity).

Moore, K., Mason, P. and Lewis, J. (2008) 'Images of Islam in the UK. The representation of British Muslims in the national print news media 2000-2008', Cardiff School of Journalism, Media and Cultural Studies. Available online at: http://cardiff.ac.uk/jomec/resources/08channel4-dispatches.pdf.

MPAC (2008) 'How YOU can help save us from a Zionist Mayor', Muslim Public Affairs Committee. Available online at: http://www.mpacuk.org/content/view/4572.

MPAC (2010) 'MPACUK take on Muslim MP Khalid Mahmood', Muslim Public Affairs Committee. Available online at: http://www.mpacuk.org/story/080410/press-release-mpacuk-take-muslim-mp-khalid -mahmood.html.

MPAC (2012) 'Will Labour steal the Bradford West by-election?', Muslim Public Affairs Committee. Available online at: http://www.mpacuk.org/story/270312/will-labour-steal-bradford-west-election.html. 
Murray, D. (2010) 'When will the Tories stop trawling for the "Muslim" vote?', The Telegraph, 3 May. Available online at: http://blogs.telegraph.co.uk/news/douglasmurray/100037671/when-will-the -tories-stop-trawling-for-the-muslim-vote/.

Nawaz, M. (2012) 'Age of extremes: Mehdi Hasan and Maajid Nawaz debate', The New Statesman, 4 July. Available online at: http://www.newstatesman.com/politics/politics/2012/07/age-extremes-muslim -mehdi-hasan-maajid-mawaz.

New Generation Network (2006) 'Race and faith: A new agenda', The Guardian, 20 November. Available online at: http://www.guardian.co.uk/commentisfree/2006/nov/20/whyweneedanewdiscourseon.

O'Toole, T., DeHanas, D., Modood, T., Meer, N. and Jones, S. (2013) Taking Part. Muslim Participation in Contemporary Governance (Bristol: Centre for the Study of Ethnicity \& Citizenship).

O'Toole, T. and Gale, R. (2010) 'Contemporary grammars of political action among ethnic minority young activists', Ethnic and Racial Studies, 33:1, 126-143.

Pandya, A. (2012) 'Galloway's victory is the last thing Britain needs', The Daily Mail, 30 March. Available online at: http://pandyablog.dailymail.co.uk/2012/03/galloways-victory-is-the-last-thing-british -muslims-need.html.

Phillips, A. (1995) The Politics of Presence (Oxford: Clarendon Press).

Pitkin, H. F. (1967) The Concept of Representation (Berkeley and Los Angeles, CA: University of California Press).

Pollard, S. (2012) 'Galloway victory is a disaster for British democracy', Daily Express, 31 March. Available online at: http://www.express.co.uk/posts/view/311608/Galloway-victory-is-a-disaster-for-British -democracy.

Purdam, K. (2001) 'Democracy in practice: Muslims and the Labour Party at the local level', Politics, 21:3, 147-157.

Seymour, M. (2012) 'Peoples, political liberalism and religious diversity', Ethnicities, 12:2, 142-160.

Siddiqui, A. (2008) 'The kiss of death?', The Guardian, 3 May. Available online at: http://www .guardian.co.uk/commentisfree/2008/may/03/thekissofdeath.

Sobolewska, M., Heath, A., Sanders, D. and Fisher, S. (2011) Religion and Minority Political Participation: Evidence from Great Britain. Available online at: http://www.esrc.ac.uk/my-esrc/grants/RES-062-23 -1953-A/read.

Staples, K. (2012) 'Statelessness and the politics of misrecognition', Res Publica, 18:1, 1-14.

Taylor, C. (1989) Sources of the Self: The Making of the Modern Identity (Cambridge: Cambridge University Press).

Taylor, C. (1994) 'The politics of recognition', in A. Gutmann (ed.), Multiculturalism and 'The Politics of Recognition': An Essay (Princeton, N.J.: Princeton University Press), 25-73.

Thompson, S. (2012) 'Freedom of expression and hatred of religion', Ethnicities, 12:2, 215-232.

Tully, J. (2000) 'Struggles over recognition and distribution', Constellations, 7:4, 469-482.

Werbner, P. (1990) 'Manchester Pakistanis: Division and unity', in C. Clarke, C. Peach and S. Vertovec (eds), South Asians Overseas: Migration and Ethnicity (Cambridge: Cambridge University Press), 331-347.

Young, I. M. (2000) Inclusion and Democracy (Oxford: Oxford University Press). 